\section{Audubon and his Journals}

Edited by Maria R. Audubon. With zoological and other notes by Elliott Coues. Vol. 1: Pp. xiv +532 . Vol. 2: Pp. viii +554. (New York: Dover Publications, Inc.; London: Constable and Co., Ltd., 1960.) 2 dollars each volume.

THESE two 'Dover books' (in stiff paper covers but suitable for rebinding in cloth) represent an unabridged and unaltered republication of the work originally issued in 1897. It consists of a biography (some 70 pp.) of John James Laforest Audubon by his granddaughter, supplemented by certain of Audubon's own journals and a number of short 'episodes' from his publications. The whole provides a picture of the personality and career of a man whose name has become in the United States-in the titles of national and local societies-synonymous with the conservation of wildlife, notably birds. Audubon was born in Louisiana, probably about 1780 , the son of a French admiral and his Spanish Creole wife. He was brought up mainly in France but returned to North America as a young man; there he settled, married, suffered many vicissitudes, and became famous as a naturalist and artist, dying in 1851.

Of special interest from the Old World point of view are the European journals, 1826-29, covering the period when Audubon worked in London and elsewhere on the publication of parts of his illustrated folio The Birds of America, now a rarity. He naturally met many contemporary figures and, while spending part of the time in Edinburgh, he had William MacGillivray as a collaborator on the scientific side. The Labrador journal, 1833, and the Missouri River journals, 1843, give a good idea of travel, conditions, and wildlife in those parts more than a century ago. The 'episodes' deal with many different matters; in so far as they are dated, they refer to the period 1808-33 and help to fill gaps where journals have not survived. LANDsborough Thomson

The Mathematical Theory of Linear Systems

By Prof. B. M. Brown. (Automation and Control Engineering Series.) Pp. xv +267 . (London: Chapman and Hall, Ltd., 1961.) 50s. net.

7 HE mathematics underlying the many analytic methods now used in modern control engineering is of necessity omitted from most of the text-books on the subject at present available, and has also not been obtainable hitherto in one book. This gap is filled by the present volume, which is the second of a series entitled Automation and Control Engineering.

The work presents clearly yet comprehensively the basic mathematics of linear systems, and in particular of feedback control systems, developed in a logical manner from a starting point no more complex than the basic concepts of differentiation and integration.

The first five chapters are devoted to introduction and to the solution of linear equations by operational, Laplace, and Fourier methods. In particular, the author stresses the value of the bilateral Laplace transform, and compares the applicability of each method in various situations. The mathematics of conventional linear systems is completed by chapters on step and impulse functions, system analysis, feedback and stability. Two chapters are then devoted to statistical methods and the optimization problem, and the final four chapters to finite difference methods and their application to sampled data systoms.

The text includes many worked examples of the methods described, and also references, and concludes with twelve substantial appendixes of topics too specialized to be included in the main development. The clear and logical treatment followed throughout is particularly attractive, and renders this book suitable as a teaching text. E. M. Deeley

The Veterinary Annual, 1961

Edited by W. A. Pool. Pp. xxiv $+406+34$ plates. (Bristol: John Wright and Sons, Ltd., 1961.) $42 s$.

$\mathrm{W}$ ITH this, its third edition, the Veterinary Annual is now firmly established, and has achieved its own distinguished place in veterinary literature. A noteworthy feature is its wide appeal; designed primarily to help practitioners to keep in touch with recent work it is to-day quite widely used by research workers, advisory officers and teachers.

Following what has become its established pattern this year's volume contains, in addition to contributed short reviews on many subjects, a number of special articles. There are eight of these dealing with veterinary medicine in West Germany; in Switzerland; Army Veterinary Services; the ecological approach to veterinary medicine in the United States; parasitological complications of intensive sheep grazing; hides, skins and leather; the physiology of the udder; animal trypanosomiases in Africa; and the unusual but topical subject of retirement from the Colonial Service. These have all been written by prominent workers with close contact with the various subjects and they add greatly to the interest of the book.

A feature is the provision of a list of selected refer. ences to each topic, quite a number of them from foreign journals. The value of the lists would be improved if each item from a foreign publication gave information on $(a)$ the language in which the original is written, and $(b)$ any abstract in English which may be available.

\section{Concise History of Logic}

By Heinrich Scholz. Pp. xv +140 . (New York : Philosophical Library, 1961.) 3.75 dollars.

$T$ HIS slender manual is a translation from the author's Abriss de Geschichte der Logik (second, unchanged edition), which appeared in 1959. Valuable as it is in many ways, it is a pity that steps were not taken to bring the sources more nearly up to date. Bochénski's Formale Logik had appeared in German in 1956, and became available in English last year. These events do not detract from the importance of the late Prof. Scholz's masterly sketch so far as it goes, but with these recent developments in view, one can scarcely expect a wide circle of readers in Britain.

The amount of material incorporated is astonishing, and this alone, with the copious notes and references, will assure a ready welcome. A good feature is the general treatment of 'types' of logic (rather than by any other classification), for this brings out the basic distinction between classical formal logic and modern formal logic. Thus, the greatness of Aristotle is seen in correct proportion, not as an obsession, and the unique position of Leibniz is well displayed.

Unluckily, however, the very personal style of the German original has made the translator's task exceptionally difficult, and some of the passages are far from idiomatic English. There are also too many tiresome colloquialisms.

The author's erudition is impressive: this alone commends the book to students who are willing to grapple with some decidedly difficult reading. F. I. G. RAWLINS 